\title{
Het Angelsaksische tijdschrift langs de meetlat
}

\section{PETER DE VOOGD}

David Reed, The Popular Magazine in Britain and the United States 1880-1960, London, The British Library, 1997. ISBN 0-7123-0417-7. VIII, 287 pp. 11 ill. in kleur, 49 in zwart/wit. $£ 45$

Dit is de eerste studie waarin de markt voor publiekstijdschriften in de Verenigde Staten en Groot-Brittannië gedurende een zo lange en formatieve periode wordt beschreven. David Reed zelf spreekt al te bescheiden over een 'mapping exercise', een poging om het onderwerp in kaart te brengen, maar hij doet veel meer dan alleen dat in deze uitputtende empirische beschrijving van de ontwikkeling van tegen de veertig toonaangevende tijdschriften. Zijn uitgangspunt is steeds het tijdschrift als technisch product: zijn bronnenmateriaal is daarom eerder een register van patenten in de grafische industrie dan een literaire encyclopedie, en eerder tabellen voor oplagecijfers dan het geschreven commentaar van eigentijdse lezers.

De opbouw van deze studie is helder. Een algemene introductie waarin de centrale vraagstelling en de onderzoeksparameters worden uiteengezet en waarin een samenvatting wordt gegeven van de voornaamste technische en economische ontwikkelingen in de tweede helft van de negentiende eeuw, wordt gevolgd door twee vergelijkende hoofdstukken, 'American Periodicals 18801900' en 'The British Scene 1880-1900'. Daarna gaan de onderzochte landen samen, in reuzensprongen: 1901-1920, 1921-1940, 1941-196o. Uiteindelijk wordt het basismateriaal in een bijlage samengevat, en traceerbaar gemaakt in een uitvoerig register.

David Reeds selectiecriteria voor de te onderzoeken tijdschriften zijn simpel: hij heeft gekozen voor de populairste tijdschriften (dat wil zeggen, die met de hoogste oplagecijfers) aan het einde van ieder decennium. Zijn voornaamste bronnen voor de bepaling hiervan zijn voor de Verenigde Staten het omvangrijke en betrouwbare Standard Rate and Data Quarterly, waarin de oplagecijfers staan van alle bij de Library of Congress gedeponeerde periodieken, en voor Groot-Brittannië het iets minder complete Monthly Circular van de 'Advertisers' Protection Society'. Bij de omschrijving van de gekozep tijdschriften wordt vooral aandacht geschonken aan technische aspecten: Reed traceert in detail de ontwikkeling van kleurendruk, fotomechanische technieken, drukpersen, mechanische typesetting, papierfabricage - alles wat productiekostenverlagend, en oplageverhogend werkt. Een en ander wordt geïllustreerd met uitvergrotingen van knap bijeen gezocht en deels uniek materiaal.

Wat de studie vooral zo interessant maakt is de onderzoeksmethode waarmee de inhoud van de tijdschriften is geanalyseerd. Ik citeer:

the basic unit of measurement in this study was the page. Subdivisions and fragments of a page were expressed as a percentage of the unit by measuring the area and calculating it in square millimetres. This was then divided by the area of the printed page and multiplied by 100 to record the result as a percentage of the unit. Each page or fragment was then allotted to a topic. An entire volume could be analysed in this way and then the whole numbers and percentages could be 

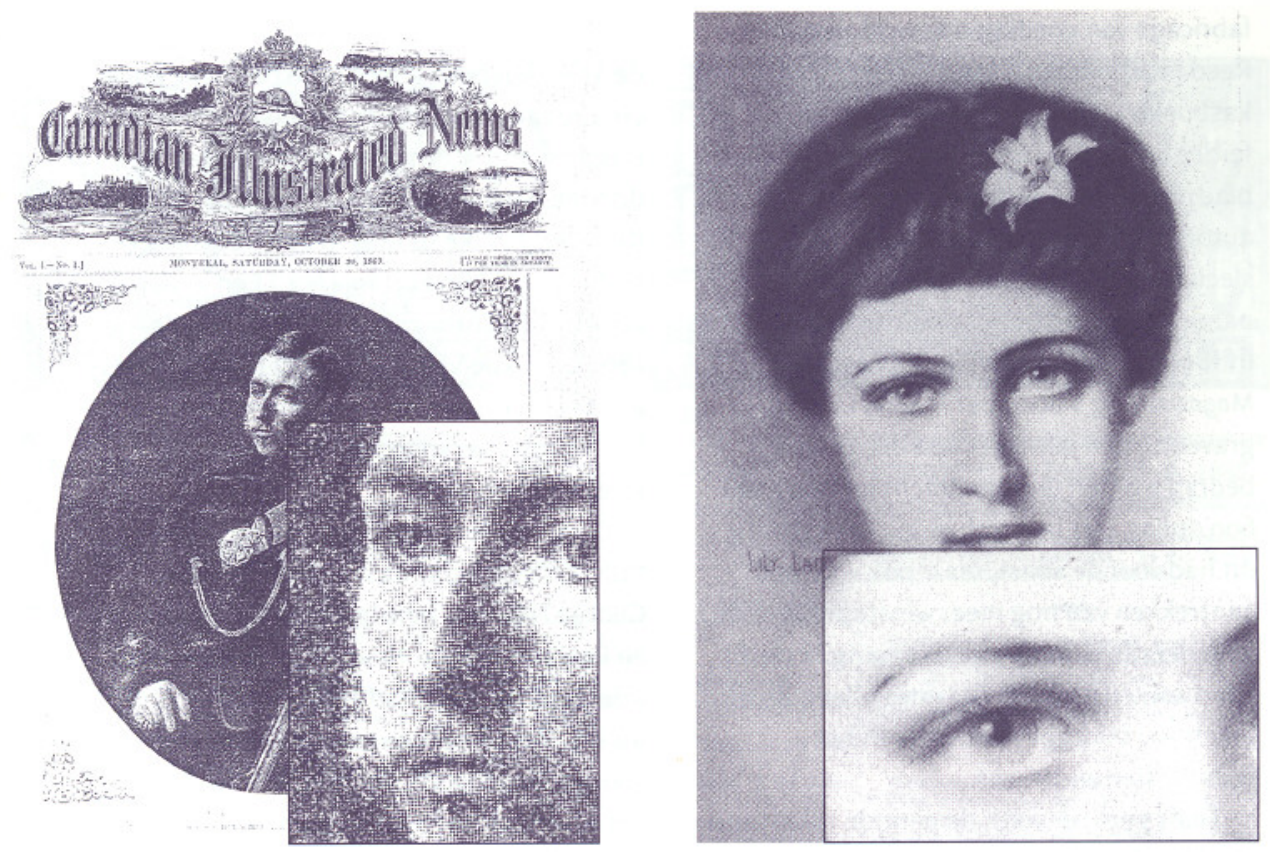

Voorbeelden van technische vooruitgang in de grafische industrie

totalled to give the breakdown for that volume. The number of pages allocated to each topic in the volume was then divided by the total number of editorial pages that constituted that volume and multiplied by 100 to express the totals for each topic as percentages of the whole. This approach gave a uniform result which was independent of page size, type, leading and the number of pages in each volume and allows the reader to concentrate on the emphasis placed on each topic by each editor at the end of each decade. (12)

Men huivert bij de gedachte alleen al. David Reed heeft tienduizenden bladzijden met meetlat en rekenmachine gemillimeterd, gedeeld, vermenigvuldigd, in grafieken ondergebracht - dat is geen 'mapping exercise' meer, dat is het in eenzaamheid tot stand brengen van een complete serie gedetailleerde stafkaarten van een tot nog toe onbekend werelddeel.

Voordat die detailkaarten kunnen worden ingetekend, schetst Reed de grotere contouren. Uiteraard komt hierbij de topografie van de Verenigde Staten en Groot-Brittannië aan de orde, en de mate waarin de infrastructuur (bijvoorbeeld van het spoorwegennet) bij- droeg aan de distributie van het gedrukte woord. Van meet af aan betrekt Reed hierbij echter ook de grafische industrie in de meest brede zin van dat begrip, waarbij ontwikkelingen in de fotografie minstens zo belangwekkend worden als de opkomst van snellere zetmachines. Zo worden verbanden gelegd die bij mij althans nooit zijn opgekomen. Eén voorbeeld uit vele:

After Gustavus F. Swift had hired Andrew J. Chase to design a refrigerated car to carry his dressed beef from Chicago to Boston in 1881, the meat, beer and photographic industries were transformed into national operations. (20)

Zelden zullen biefstuk, pilsjes en (van fotografisch materiaal afhankelijke) tijdschriften in zo'n onderlinge samenhang zijn gepresenteerd, een samenhang die overigens alleen voor de specialist (die weet dat nietontwikkelde film slecht tegen de warmte kan) direct duidelijk zal zijn. In het boeiende maar eveneens zeer technische (en dus voor de leek grotendeels onbegrijpelijke) hoofdstuk 'The Great Printing Revolution' wordt speciaal ingegaan op de opkomst van de autotypie (half-tones) en de impact van de 
fabricage van goedkoop kunstdrukpapier. Reed heeft uitvoerig rondgeneusd in de kasboeken, en dat levert verhelderende feitjes op als dit: rondom 1900 kostte een bladzijdegrote houtsnede al gauw \$ 300 ; een autotypie van dezelfde omvang kostte slechts $\$ 20$. Het is duidelijk dat dit de toename van geïllustreerde katernen verklaart. In 1890 gaf de Century Illustrated Monthly Magazine nog $\$ 8000$ per maand uit aan graveurs, tien jaar later kon dat enorme bedrag worden teruggebracht tot nog geen Goo dollar. Het laat zich raden welk gevolg dit had voor de winst, maar ook voor het aantrekken van nog meer winstopleverende adverteerders. Reed gaat uitvoerig in op dit soort zaken, en heeft daarmee alleen al een prachtige bijdrage geleverd aan het tijdschriftenonderzoek.

Zoals gezegd wordt de periode 1880-1900 uitvoerig beschreven in twee contrasterende hoofdstukken. De door Reed gevolgde nauwkeurige rekenmethode ontkracht een aantal algemeen geaccepteerde 'feiten' over de Amerikaanse situatie. Zo wordt overtuigend bewezen dat de aangenomen vulgarisatie van de Amerikaanse publiekspers gewoonweg niet heeft plaatsgevonden. Leidende tijdschriften als Harper's, Scribner's en The Ladies Home Journal houden een duidelijk hoogculturele inhoud, en pas tegen de eeuwwende ondergaat Munsey's Magazine, als enige, onder het hoofdredacteurschap van Richard Titherington zo'n vulgarisatie: met veel (geïllustreerde) aandacht voor de interieurs van de rijken, voor actrices, en, interessant genoeg, voor godsdienst (voor het eerst!). Dit alles wordt op goedkoop papier gedrukt maar wel met een opvallend veelkleurendruk omslag, veel advertenties, en inderdaad stevige winst.

In deze periode (1880-1900) is de ontwikkeling in Groot-Brittannië in technische zin vergelijkbaar, maarverder geheel verschillend. In de Verenigde Staten is de markt vrijwel uitsluitend gericht op de middenklasse, maar in Engeland speelt het standsverschil een beduidende rol, en zijn er in feite twee markten: een betrekkelijk kleine voor de middle en upper-middle class (net als nu wordt in de echte upper class niet gelezen), en een populaire voor de lower class. (De laatste heeft een interessante voorgeschiedenis in de arbeidersbeweging die de politieke emancipatie van de arbeiders begeleidde met de uitgave van The Penny Magazine, uitgegeven door de 'Society for the Diffusion of Useful Knowledge', die in 1832 al een weekoplage had van 209.000 exemplaren.) Een ander verschil is zichtbaar in de distributie: de verkoop, in de Verenigde Staten veelal per abonnement, verliep in Engeland voornamelijk via vaste verkooppunten - zoals nog steeds het geval is.

De grootste nieuwkomer op de Britse tijdschriftenmarkt was in deze periode George Newnes, gevolgd door Harmsworth en Pearson. Vooral Newnes' buitengewoon interessante weekblad Tit-bits is de moeite waard. Het verscheen vanaf 1881 en was spotgoedkoop, ook om te produceren, want het bevatte aanvankelijk geen illustraties en de meeste tekst was uit andere bronnen gejat of werd gratis door lezers geleverd. Newnes nam geen genoegen met een stevige winst, maar bleef op de meest opmerkelijke manieren pogingen doen zijn oplage te vergroten. Toen deze in 1883 vastlag op 200.000 exemplaren per week, bedacht Newnes een prijsvraag (hoofdprijs: een huis met zeven kamers), en loofde hij duizend pond uit (een gemiddeld jaarinkomen in die tijd) voor het beste feuilleton door een lezer geschreven. Ook organiseerde hij schatzoektochten: op verscheidene plaatsen in Engeland werd vijfhonderd pond verstopt aanwijzingen waren op slimme wijze verwerkt in korte verhalen, en natuurlijk kreeg men pas genoeg aanwijzingen bij elkaar als men een aantal weken de tekst van Tit-bits had gespeld. Lezers die zich abonneerden kregen ook gratis verzekeringen aangeboden. In 1890 was Tit-bits met een oplage van 350.000 het meest succesrijke tijdschrift van het Verenigd Koninkrijk. Leopold Bloom, in James Joyces Ulysses, leest het 's ochtends geboeid, en droomt ervan op een dag een winnend verhaal te schrijven.

Razend populair was ook The Boy's Own Paper, uitgegeven door de 'Religious Tract Society' voor de lagere middenklasse. Reed hanteert de grappige afkorting BOP (en dus wordt het iets later ook uitgebrachte Girl's Own Paper vanzelf GOP): beide tijdschriften 


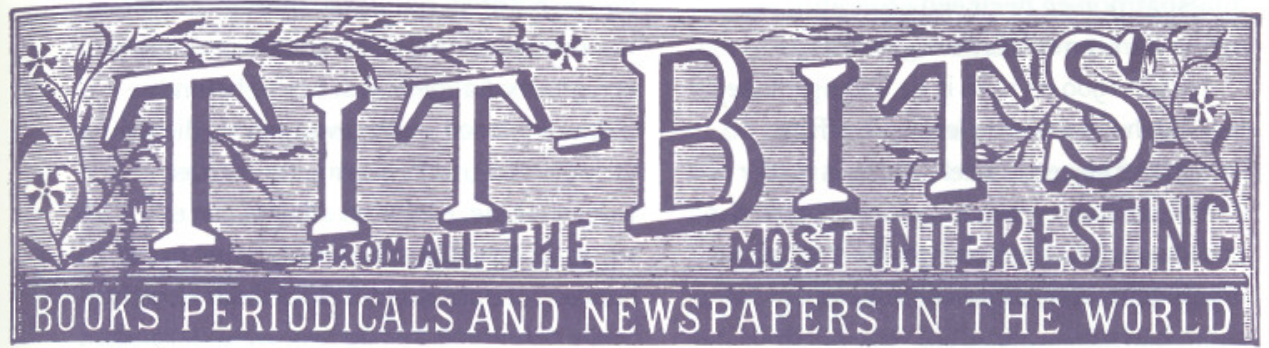

CONDUCTED BY GEO. NETNES.

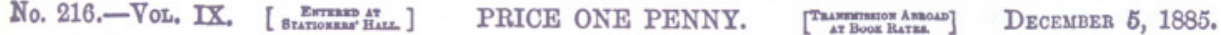

\section{"TIT BITS" CHRISTMAS PRIZES.}

Aspreviously announced we o Ter forty-eight prizes of one guinea each, being one for each of the columns of the Cluristmas number.

All competitions must arrive by Saturday, the 19th December, and the number of the competition be marked on the outside of the envelope.

We cannot under any circumstances return contributions.

1. The neatest repartee.

2. Best story about tho clections.

8. Funniest anecdote connected with the telephone.

4. Most curious case of mistaken identity.

b. Most intoresting story of an escapo from prison.

6. Best story of a missing letter.

7. Slost startling instance of wrongful conviction.

8. Best defonce of the "Good old times."

9. Best defonee of modern times.

10. Best instance of the advantages of being tall.

11. Bost instance of the advantages of being short.

12. Slost iuteresting experiences of house-hunting.

13. What is the most embarrassing position a man can be placed in ?

14. The most interesting instance of child-heroism.

15. Best story of the result of eatching cold.

16. Three most outrageous puns.

17. Dlost intoresting account of looking for a situe tion.

18. Mfost interesting story of experiences as a 'cyclist.

10. Slost curious experiences of engaging a servant,

20. Account of the most disastrous effects of telling

21. Slost remarkable recovery of iost property.

22. Bost example of the result of deciding too quickly.

23. Best example of the resultof hesitating too long.

24. Dost wonderful instance of a fulfilled dream.

25. Most interesting story about making a will.

26. Most interesting story of the result of a quarrel.

27. Bcst story of an old maid.

28. Best story of an old bachelot.

22. Strangest effect of giving the wrong medicine,

20. Most remarkable story of a lost opnortunity.

31. Siost humorous story of the rosult of writing two lotters and putting them in the wrong

82. Best game for a Christmas party.

29. Dest story of a pawn-tickot.
TIIE FOLLOTIYG IITST BE ORIGISAL.

34. Stost ingenious form of adsertisement.

35. Best statement of hov a man and wife, with one boy, aged thirteen, and two girls, nged
eight and nine, should spend an income of E 300 a year living in a town.

36. Best plot for a norel.

37. Most humorous description of a baby.

Best satire on the Englialu custom of woaring a tall black hat.

39. Cleverest prodiction of the events of the noxt fifty years.

40. Best speech proposing the health of the ladies at a Cluristmas party.

41. Dust speech responding to ditto.

42. Sost approved statement of how to dress like a lady on 205 a year.

43. Slost approred statement of bow to dress like a rerorch sthtement of b

41. Best description of a holiday for a $f 10$ noto.

45. Cleverest adverse criticism of Tit. Bits.

46. Cleverest favourable criticism of Tit-Bits.

47. Best comments on the abore prizes in prose.

48. Best comments on the above prizes in verse.

Ir is said that a blind woman can knit faster than one with goodeyer. She doesu't look out of the window every five minutes.

coee

THE most smusing man in the world is a Frenchman in a passion trying to vent his rage in English - "liy gar, you call my, vife a voman three -cveral times once more, and 1 vill call the watch house and blew off your Lrain like a candle."

"Let me see," said the nurse to a sick man; "the doctor said ono teasponful erer $/$ ten minutes. That make : six every hour ; say seventytwo during the night. I sliail give haim seventy two spoonfuls right away, and have a chance to get a little sleop my self."

\section{0}

"Sır,", began a creditor who met one of his victims in the street the other day," I sent you a bill in June ?" "les, sir." "And again ii August ?" "Yes, sir." "And again in Uctolier?" "les, sir." "And I liresume you received one the other day " I did, sir." "Well, sir-well, sir t" flu-tered the creditor. "Well, you needn't feel so stuck ul, over it," replied' the other, as be lighted a six. penny cigar. "There are firms in this town who aend me bills every two weeks in the year, and they never stop ne in the strect to Lrag about it either. I detest such egotisin, sir! Gical
FirTy-sargn years ago people were gazing in wonder on their first gns light. To day they at

0006

Is England young gentlemen speak of their fathers as "the governor," "pater," "the over seer," ete. In America they say "dad," "the boss," or " the old man." In beathen countries they say "father." but they are a long way telind the aga.

cove

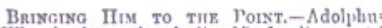
"What is that noise, darling of 1)arling : "U it's only pals. Ever since he read in the papers that it is thought breach of promise of marriaye will be abolished, be is always going about crack. ing bis horsewhip." Adolphns: "Wh ! (lauss reflectively.) Well, would it-er--be tioub.ing you to-er-name the day?

\section{6}

A risascier used to meet his shareholiters once every year. The p'ace of mecting was an immense room with neither scats nor table in it. The financier road out his report and thien alded: "All those who approve the procee tings of the Board will stand up and the others vill sit down." Of course nolooly sat down, anil tho financier concluded by sayin" " $\Lambda$ pproved unan" mously.

0000

A urotcat purna! advises its readers "not to ell when frightened, as it only increaves terrot eep control of yourself ani do something to calm your nerves. Juat s the do-trine. If yon find the house is on fire don tump up and ych loud enough to oring all the cines in

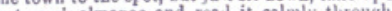
ast year s almanac and rcad it calmly tirtorgh. by the time you finish it you will perceive save ane out or burned the house dowa

\section{0}

AN I ish officer rang his bell so often tlat no servant the landlady could hire wotid stop in the house, or could stind the running upsta: ${ }^{2}$. The oflicer consequently received notice to quit, which being unwilling to do, and finding the cause of warning, he promised never to ring histe'l azain apon this understanding he retired to his af art ment. In about half an hour the whole huzas was alarmed by the report of pistol, in the eapain's room. I'p ru-hed tho land:aty, the lod zers, and the servants, and burst open the do $x$ in the full expectation of some dr aifu catastrophe. "('offee," coolly sai t the rajtain. (O) thit expressing surpise, the lodecr cricd "W i,y, as yo idil not like m: to staan bol van de karaktervormende verhalen, die de jeugd goed voorbereiden op een functie in het Britse wereldrijk, met veel aandacht voor de hulpbehoevendheid van de inboorling en de verzwakkende uitwerking van masturbatie. Conan Doyle en Jules Verne werden in Engeland dankzij BOP en GOP beroemd.

Overigens ontkracht Reed ook in dit hoofdstuk een oude theorie: dat de opkomst van deze massatijdschriften te danken was aan de als gevolg van de 'Forster Education Act' verhoogde geletterdheid. Reed stelt dat die geletterdheid al door het Chartisme en de 'Society for the Diffusion of Useful Knowledge' bevorderd was: de toename van de markt kan direct worden gerelateerd aan een toename in het consumptieve beste- 
dingspatroon en heeft een economische eerder dan een educatieve grondslag.

Tussen 1900 en 1920 is de belangrijkste technische innovatie die van de offset lithografie geweest. Veel nieuws is verder niet toe te voegen aan het globale beeld dat in de voorafgaande hoofdstukken tot stand is gebracht. Wel worden door Reed op slimme wijze via niet altijd voor de hand liggende invalshoeken bepaalde merkwaardigheden verklaard. Zo was de Amerikaanse Saturday Evening Post een buitengewoon saai en behoudend blad, en desondanks een van de best lopende. Reed toont met zijn vierkantemillimetermethode aan dat een relatief groot deel van de inhoud inspeelde op de belangstellingssfeer van de belangrijke agrarische sector - een doelgroep waar de meer literair ingestelde concurrerende tijdschriften minder aansloegen. Dat wil niet zeggen dat de Post de literatuur verwaarloosde-F. Scott Fitzgerald debuteerde erin. Ook wordt een inzinking in de oplagecijfers bij de eveneens Amerikaanse Ladies Home Journal direct gerelateerd aan een serie artikelen over seksualiteit bij kleine kinderen dat kostte in één klap 75.000 abonnees.

In dit hoofdstuk maakt Reed weer duidelijk hoe naast inhoudelijke en technische aspecten, de economische ontwikkeling, met name in de besteedbare lonen van mensen, direct zichtbaar wordt in de oplage en het redactiebeleid van publiekstijdschriften. De verschillen tussen Amerika en Engeland worden ook heel duidelijk: in de VS verschijnen de tijdschriften over het algemeen maandelijks en richten ze zich op beter ontwikkelde vrouwen, in het Verenigd Koninkrijk is het weekblad dominant en bestaan er twee, overwegend mannelijke doelgroepen aan beide zijden van de Britse standenmaatschappij. In Amerika verloopt de verkoop voornamelijk door middel van abonnementen, in Engeland in losse verkoop via vaste verkooppunten.

En alweer bevat de Engelse geschiedenis een amusante schurk: de oprichter van het nieuwe weekblad John Bull, Horatio

Bottomley, die Reed met enig overstatement beschrijft als 'one of the most audacious, dishonest and scandalous characters to figure in British public life during the last hundred years' (135). Horatio Bottomley was een grootschalige fraudeur (hij belandde uiteindelijk ook in de gevangenis), die de formule van Tit-Bits overnam en verder vulgariseerde, en vooral dankzij een extreem-nationalistische houding het in de Eerste Wereldoorlog tot marktleider bracht.

De periode tussen de twee wereldoorlogen wordt bepaald door verdere technologische ontwikkelingen, met name op het gebied van de offsetdruk en grafische technieken. Sterk verbeterde inktsoorten sloten mooi aan bij nieuwe papierproductieprocessen, en dit leidde weer tot een enorme toename van illustraties, en de opkomst van de 'picture magazine'. Inhoudelijk werd de invloed van nieuwe massamedia als film en radio zichtbaar (Radio Times wordt het grootste weekblad in Engeland), maar fictie blijft belangrijk. Evelyn Waugh en Robert Graves schrijven voor John Bull, terwijl de grote Amerikaanse schrijvers verhalen blijven produceren voor de populaire week- en maandbladen.

De laatste onderzochte periode (19411960) levert betrekkelijk weinig nieuws op. Litho's kunnen op plastics (in plaats van steen of metaal) worden gemaakt, 'Photomat'-papier zorgt voor de rest. In 1944 wordt voor het eerst een cellofaan drukproef gebruikt, uit Chicago overgevlogen, om in Los Angeles een editie van Time te offsetten. Twee jaar later komt in Parijs een in Hawaii vervaardigde editie uit. Reed schetst de wereldwijde opkomst van Life en Reader's Digest, en besteedt ook enige aandacht aan een voor gender studies interessant gegeven. Tijdens de Tweede Wereldoorlog hadden de Britse propagandaministeries regelmatig contact met de op vrouwen gerichte publieksbladen, teneinde de oorlogsinzet van vrouwen te bevorderen. Maar na 1945 werd de klok resoluut teruggedraaid naar de vooroorlogse status-quo. Op aandringen van de na-oorlogse regering maakten emancipatoire rubrieken plaats voor rolbevestigende breipatronen.

In 1950 werd in Engeland een nieuwe, en tot de dag van vandaag uiterst succesrijke, nieuwe markt aangeboord met het konink- 
lijk huis. De methode van Reed maakt overtuigend duidelijk dat dit pas toen begonnen is - daarvoor speelden koningshuizen nauwelijks een rol in de onderzochte tijdschriften. In deze laatst onderzochte periode wint de illustratie het van de tekst, wordt de concurrentie van de televisie zeer zichtbaar, en blijkt met name de filmindustrie een toenemende (en voor de uitgevers gratis) bron van informatie te zijn.

In Reeds studie is uiteindelijk merkwaardig weinig te zien van de grote politieke ontwikkelingen die de wereldgeschiedenis in de onderzochte periode kenmerken. De Boerenoorlog krijgt relatiefveel aandacht, de Eerste en Tweede Wereldoorlog (en de Koude Oorlog) komen eigenlijk alleen maar in bijzinnen ter sprake. Ook wordt met geen woord gerept over een vorm van weekblad die een enorme impact heeft gehad in Engeland: die van de zondagsbladen, zoals The Sunday Times en The Observer.

Ernstiger kritiek kan geuit worden over het feit dat Reeds'boek behoorlijk lezersonvriendelijk is. Complexe technische zaken worden zonder enige uitleg gepresenteerd, de stijl is verre van helder, en het kost vaak enige malen herlezen om erachter te komen over welk tijdschrift Reed het in een deel van een alinea nu eigenlijk heeft. Een kenmerkende passage gaat als volgt:

From a dead start, the Saturday Evening Post had increased in weight as the decade progressed. In 1897, when Curtis bought it, the weekly was selling 2,231 copies per issue and raised slightly less than $\$ 7,000$ in advertising revenue. By 1900 the circulation was claimed to be 250,000 and the page rate was $\$ 800$. Because this rate was disproportionately high relative to sales, advertising was slow in appearing and the magazine lost $\$ 1.25$ million before it turned the corner. Yet, by the decade's end, its 1576 pages plus 26 front covers for the periode January to June 1910 featured a total of 788.69 pages of paid insertions. At $\$ 3,600$ a page or $\$ 4,500$ for the back cover, that suggests an income from advertising of about $\$ 2,800,000$ for the halfyear, say $\$ 5.5$ million gross for the whole of $1910[\ldots]$ (105)
Enzovoorts, tientallen bladzijden achtereen, met teveel cijfers achter de komma om te blijven boeien.

De nadruk die Reed plaatst op de esthetiek van de gedrukte bladzijde heeft geen uitwerking gehad op zijn eigen lay-out. En die is inderdaad van hemzelf. Blijkens de colofon is het hele boek door de auteur gezet, uit de Caslon 224 Book, en dat had hij beter niet kunnen doen. Want dat 8-punts lettertje over een zetbreedte van liefst 14 centimeter, en 47 zetregels op een bladzijde met de uiterst magere margeprogressie van $1.5,2,2$, en $2,5 \mathrm{~cm}$ - dat alles leidt tot verschrikkelijk onleesbare bladzijden. Ook is het jammer dat de kleurenpagina's niet bij de relevante tekst, maar met z'n allen bij elkaar in een katern voorin zijn afgedrukt, zonder dat daar een aanwijsbare reden voor is, want het hele boek is gedrukt op eerste kwaliteit kunstdrukpapier.

Maar wie afhaakt op de stijl en de eindeloze opsomming van diverse feiten, of wie door de verschrikkelijke typografische vormgeving vermoeid raakt, doet er goed aan zich te storten op het buitengewoon instructieve basismateriaal waar Reeds commentaar op stoelt, en dat te vinden is in 26 bladzijden vol tabellen waarin de inhouden van 39 tijdschriften worden beschreven in termen van absolute percentages voor een groot aantal verschillende categorieën. Natuurlijk zal vaak de keuze van categorie lastig zijn geweest, maar een en ander is verfijnd genoeg, en dankzij de rekenmethode van Reed ook overtuigend genoeg, om veel intuïtieve oordelen over de inhoud van de geanalyseerde tijdschriften op losse schroeven te zetten dan wel vaste grond te geven.

Het geheel wordt afgesloten met een heel mooi register, op zich een prachtig onderzoeksapparaat, geordend op persoonsnaam, titel van tijdschrift en onderzoeksthema's. Dat register maakt de hele complexe materie uiteindelijk inzichtelijk, en zal toekomstige onderzoekers een weg wijzen in Reeds 'mapping exercise'. Wie zich een zo compleet beeld als nu maar mogelijk is wil vormen van de ontwikkeling van het publiekstijdschrift in de vs en GrootBrittannië, kan niet om Reeds studie heen. 